\title{
Towards the Development of Sustainable Ground Improvement Techniques-Biocementation Study of an Organic Soil
}

\author{
M. U. Safdar ${ }^{1} \cdot$ M. Mavroulidou ${ }^{1}$ (D) M. J. Gunn ${ }^{1}$ - D. Purchase ${ }^{2} \cdot$ C. Gray ${ }^{3} \cdot$ I. Payne ${ }^{4}$. \\ J. Garelick ${ }^{5}$
}

Received: 18 February 2021 / Accepted: 31 May 2021 / Published online: 6 August 2021

(C) The Author(s) 2021

\begin{abstract}
Ongoing research effort is dedicated to the development of innovative, superior and costeffective ground improvement techniques to mitigate natural and man-made hazards while minimising waste and other environmental impacts. In this context, the naturebased process of biocementation of soils has been proposed as a potentially more sustainable technique than conventional chemical ground improvement practices. This paper focuses on the biocementation of an organic soil of the UK railway network. Having recently proven the feasibility of biocementing this soil using indigenous ureolytic bacteria, in this paper, the authors perform a parametric study to identify treatments successful in increasing the strength of the soil. Selected treatments are then applied to the soil to assess its volume change during consolidation, secondary compression and shrinkage upon drying. The results show that, depending on the treatments used, biocementation has increased the unconfined compressive strength by up to $81 \%$ compared to that of the control samples. For selected treatments and the range of water contents tested (55-33\%), shrinkage upon drying reduced by $16 \%$, while the volumetric strains of the soil upon 1-D compression reduced by $32-47 \%$. This was reflected in the values of the coefficient of volume compressibility and the coefficient of secondary compression (the latter either reduced by up to an order of magnitude or secondary compression was not observed altogether in the testing period). Overall, the results proved that biocementation improved considerably the mechanical properties of the organic soil, which gives promise for addressing the settlement problems of this soil.
\end{abstract}

Keywords Biocementation · Organic soil · Urea hydrolysis

M. Mavroulidou

mavroum@1sbu.ac.uk

Extended author information available on the last page of the article 


\section{Introduction}

Organic soils are a continuing challenge to civil engineers, as they are highly compressible and subject to settlements, negatively impacting on civil engineering infrastructure. Settlements are due to a number of mechanisms of which consolidation, secondary compression, shrinkage upon drying and wastage due to oxidation linked to fluctuating groundwater levels and drought [1]. Common techniques to address these problems for new construction include piling, the use of lightweight fill materials or ground improvement techniques involving preloading and consolidation of the soil with vertical drains, ground water table lowering or vacuum drainage. In addition to these, various chemical soil stabilisers such as various grouts or calcium-based stabilisers, e.g. cement or lime, are also commonly used. Chemical treatments can be injected into or mixed in place with the problematic organic soil in order to increase its strength and reduce post-construction settlements. Although conventional chemical ground improvement methods for foundation soils and earthworks may be successful in minimising severe damage, they commonly suffer from high costs, environmental side effects, limited lifetime and interruption to services. Therefore, the development of innovative, superior and cost-effective soil improvement techniques to mitigate natural and man-made hazards, while minimising waste and other environmentally impact, is a field of ongoing intensive research effort.

In this context, biocementation of soils has been proposed as a potentially more sustainable and superior soil stabilisation technique than chemical grouts or other common soil stabilisers [2]. Chemical grouts can be potentially toxic/hazardous [3], unlike microbially produced grouts, while common soil stabilisers such as cement or lime are linked to high $\mathrm{CO}_{2}$ emissions. On the other hand, biocementation is a nature-based solution, inspired by the natural process of biomineralisation, i.e. the biological production of minerals through the metabolic processes of living organisms. Biocementation thus uses the metabolic action of non-pathogenic and renewable microorganisms to precipitate minerals that can act as cementing agents i.e. biocements for the soil, thus improving its engineering properties. Whereas a number of possible metabolic pathways can produce biocements, the most commonly investigated mechanism has been the precipitation of calcium carbonate $\left(\mathrm{CaCO}_{3}\right)$ through urea hydrolysis, using ureolytic bacteria to produce urease enzyme, thus accelerating the rate of urea hydrolysis by many orders of magnitude compared to the spontaneous reaction [4]. This is considered to be a straightforward and easily controlled mechanism of $\mathrm{CaCO}_{3}$ precipitation [5].

The multi-step chemical reaction process of $\mathrm{CaCO}_{3}$ precipitation by urea hydrolysis can be described as follows [6]: first, $1 \mathrm{~mol}$ of urea $\left[\mathrm{CO}\left(\mathrm{NH}_{2}\right)_{2}\right]$ is hydrolysed intracellularly to $1 \mathrm{~mol}$ of ammonia $\left(\mathrm{NH}_{3}\right)$ and $1 \mathrm{~mol}$ of carbamate $\mathrm{NH}_{2} \mathrm{COOH}$ (Eq. 1), which spontaneously hydrolyses and forms $1 \mathrm{~mol}$ of ammonia and $1 \mathrm{~mol}$ of carbonic acid $\left(\mathrm{H}_{2} \mathrm{CO}_{3}\right)$ (Eq. 2).

$$
\begin{gathered}
\mathrm{CO}\left(\mathrm{NH}_{2}\right)_{2}+\mathrm{H}_{2} \mathrm{O}(\text { with urease }) \rightarrow \mathrm{NH}_{2} \mathrm{COOH}+\mathrm{NH}_{3} \\
\mathrm{NH}_{2} \mathrm{COOH}+\mathrm{H}_{2} \mathrm{O} \rightarrow \mathrm{NH}_{3}+\mathrm{H}_{2} \mathrm{CO}_{3}
\end{gathered}
$$

These products subsequently equilibrate in water, forming bicarbonate $\left(\mathrm{HCO}_{3}^{-}\right)$and hydrogen ions $\left(\mathrm{H}^{+}\right)$(Eq. 3), and then, the $2 \mathrm{~mol}$ of ammonia will combine with $2 \mathrm{~mol}$ of water forming 2 mol of ammonium $\left(\mathrm{NH}_{4}^{+}\right)$and 2 mol of hydroxyl ions $\left(\mathrm{OH}^{-}\right)$(Eq. 4). 


$$
\begin{gathered}
\mathrm{H}_{2} \mathrm{CO}_{3} \leftrightarrow \mathrm{HCO}_{3}^{-}+\mathrm{H}^{+} \\
2 \mathrm{NH}_{3}+2 \mathrm{H}_{2} \mathrm{O} \leftrightarrow 2 \mathrm{NH}_{4}^{+}+2 \mathrm{OH}^{-}
\end{gathered}
$$

The local increase in $\mathrm{pH}$ due to the hydroxyl ions shifts the bicarbonate equilibrium, leading to the formation of carbonate ions (Eq. 5):

$$
\mathrm{HCO}_{3}{ }^{-}+\mathrm{H}^{+}+2 \mathrm{NH}_{4}{ }^{+}+2 \mathrm{OH}^{-} \leftrightarrow \mathrm{CO}_{3}{ }^{2-}+2 \mathrm{NH}_{4}^{+}+2 \mathrm{H}_{2} \mathrm{O}
$$

Hence, the precipitation of $\mathrm{CaCO}_{3}$ occurs in the presence of soluble calcium ions $\left(\mathrm{Ca}^{2+}\right)$ :

$$
\mathrm{Ca}^{2+}+\mathrm{CO}_{3}{ }^{2-} \leftrightarrow \mathrm{CaCO}_{3} \downarrow
$$

The urea hydrolysis process for the precipitation of calcium carbonate mediated by ureolytic bacteria and predominantly Sporosarcina pasteurii was used successfully mostly for sands (e.g. [7-12], amongst many other) and has been widely discussed in a number of recent review papers (e.g. [13-17] amongs many other). It has however been less well investigated for other soil types. In particular biocementation of organic soils was very rarely attempted, as the organic soil is thought to be a difficult soil to treat by biocementation due to a number of reasons put forward in the literature: the organic matter content can prevent calcite precipitation by coating existing $\mathrm{CaCO}_{3}$ crystal surfaces, thus blocking their nucleation sites and preventing homogeneous crystal growth; soluble organic ligands and other organic matter are known to inhibit of $\mathrm{CaCO}_{3}$ precipitation and crystal growth; the $\mathrm{pH}$ of organic soils and peats is often too low thus unfavourable for calcite precipitation; finally, organic and peat soil structure is complex, consisting often of naturally cemented aggregated particles with large macropores but the micropores of the organic soil are small. The complex pore network may affect entry and free movement of microorganisms in the soil and can influence the kinetics of the reactions in terms of diffusion of reactants to reaction sites and by providing reaction surfaces [18-22]. This can result in reduced $\mathrm{CaCO}_{3}$ precipitation in organic soils compared to sands [20], thus potentially low success of the technique. The few research works studying the biocementation potential of organic soils include Canakci et al. [22, 23], who performed a feasibility study of biocementation of an organic soil from Sakarya region, Turkey, using a $S$. pasteurii strain. The two papers reported up to $16 \%$ and $20 \% \mathrm{CaCO}_{3}$ precipitation, respectively, after repeated treatment supply over several days. Shear box tests showed some shear strength increase reflected in the angle of friction and cohesion of the soil, and a change in the behaviour from that of a loose soil, when the soil was untreated, to a dense soil for the biotreated soil, which can be attributed to $\mathrm{CaCO}_{3}$ precipitation. One-dimensional consolidation tests showed a reduction in the coefficient of consolidation, which was attributed to bioclogging and a reduction in the compression index at low stress levels of 11-45 kPa. SEM-EDS analysis confirmed the presence of $\mathrm{CaCO}_{3}$ crystals on the surface and pores of the organic soil particles and showed well-pronounced Ca EDS spectra. The same group used successfully microbially induced calcite precipitation to reduce the permeability of the peat soil through bioclogging [24]. Sato et al. [25] assessed the feasibility of Hokkaido peat soil solidification by enhancing the urease activity of indigenous ureolytic microbes; they found this to be possible based on strength increases and recommended further research. An earlier 
study on comparative biocementation of Kushiro peat and three sand soils carried out by members of the same group [26] showed interestingly that in terms of $\mathrm{CaCO}_{3}$ precipitation amount and efficiency, the peat soil was the best, compared to the three sands, leading to the conclusion that bio-solidification of peats, previously considered difficult to achieve, would be feasible. Other works by the University of Coimbra studied the effect of organic matter content on calcite precipitation using urease enzyme from jack bean rather than bacteria. Mixes of a native organic soil with a clayey sand soil at contents of up to $11.3 \%$ by mass, treated enzymatically, were found to have increased strengths, as a result of $\mathrm{CaCO}_{3}$ precipitation of contents of up to approximately $1.5 \%$ [27]. The precipitation of $\mathrm{CaCO}_{3}$ was maximised for an organic matter content of about 9-10\%, which corresponded to the highest strength gains. It should be noted that the $\mathrm{pH}$ of the organic soil was 7.65 and that throughout the treatment the $\mathrm{pH}$ was maintained close to 8 , which favours calcite precipitation. The increased brittleness of the treated soil samples was also consistent with the typical stress-strain behaviour of soils stabilised with conventional chemical stabilisers such as cement or lime. However, in other studies of the group [21, 28], the enzymatic treatment of a natural fine-grained organic soil of an organic matter content of $11 \%$ did not have a positive effect on the strength. A reason put forward for this was that SEM analysis showed that the organic matter was coating the mineral soil particles, thus potentially hindering the formation of bonds between the soil particles and the $\mathrm{CaCO}_{3}$ crystals. However, the low $\mathrm{pH}$ of 4.32 of the organic soil in the latter study should also be noted, as an unfavourable factor for calcite precipitation.

Recent work by the authors [29, 30] has proven the feasibility of biocementing peat fens soil of the Nordelph Peat formation, taken from a site of the East Anglia railway network route. This is a soft, unstable organic foundation soil of ca. $88 \mathrm{~km}$ of East Anglia railway embankments, subject to severe long-term settlements, causing regular emergency speed restrictions (ESRs) and temporary speed restrictions (TSRs) to be put in place in this area of the railway network. According to Network Rail partners, this leads to delays incurring up to $£ 1 \mathrm{~m} /$ year delay minute costs to the company for some of the worst sections, and a high demand on local track maintenance resources with costs amounting to over £1Million per 5-chain (100m) of track. Similar settlement problems were reported at 162 sites of the road network in the Fenlands area (Cambridgeshire); for instance, during the 2012 drought, local councils required $£ 10$ million to fund urgent repairs of damaged roads due to settlements [31].

To prove the feasibility of biocementing this organic soil, the authors isolated and used indigenous ureolytic bacterial strains from the in situ soil, as opposed to the vast majority of previous works that used exogenous bacteria. The use of exogenous bacteria could present issues of competition with indigenous species and adaptability in the new environment. Biocementation was proven based on observations of statistically significant increases in the unconfined strength and calcium carbonate content of the organic soil [30].

Following from this pioneering work, the aim of the presented research is to implement different treatment compositions and curing times, in order to identify a range of bestperforming treatments that can stiffen the highly compressible solid matrix of the organic soil thus reducing settlements linked to the various causes mentioned earlier. For selected treatments, the effect of biocementation on the volumetric changes of the soil before and after treatment will then be evaluated for the possible causes of undesirable settlement based on (a) oedometer testing to assess biocementation effects on consolidation and secondary compression settlements and (b) measurements of shrinkage upon drying and respiration tests, to assess whether biocementation helped reducing air-drying shrinkage and oxidation respectively. 


\section{Materials, Methods and Processes}

\section{Soil Sample Characterisation}

The soil used in this study came from two boreholes at an East Anglian railway site. The properties of the sample retained for testing in its as-received state were determined as shown in Table 1. The soil was identified as sandy amorphous peat according to BS EN ISO 146881:2018 [32]. This was based on its organic content which was $>20 \%$ and the sand size particle content of $>50 \%$, as well as the fact that it was of mushy consistency and no visible plant structure. The samples had a low natural moisture content, which is consistent with a humified/ decomposed organic soil. Based on its ash content by dry weight, which was $<25 \%$, the soil is equally classified as peat (basic sapric peat) according to ASTM D4427-92 [33]. Further details on the sample characterisation are presented in Safdar et al. [30].

\section{Microbiological Study}

A detailed description of the microbiological study was provided in Safdar et al. [29, 30]. Therefore, only a summary of the procedures is presented here. Bacteria isolation was performed on $1 \mathrm{~g}$ of soil from each peat soil sample, diluted in sterile distilled water at the required dilution. The diluted soil solution $(1 \mathrm{~mL})$ was immediately plated out onto the Tryptic Soy Agar plate (TSA, Oxoid, UK), incubated at $25{ }^{\circ} \mathrm{C}$ for 3-7 days. Colonies that showed considerable growth (based on plate counting) were streaked onto B4 Agar plates. B4 medium ( $\mathrm{pH} 7.3$ ) consists of $0.4 \%$ yeast extract, $0.5 \%$ dextrose, $0.25 \%$ calcium acetate and $1.4 \%$ agar [41]. It was selected as a preferred medium for studying mineral precipitation in vitro, in particular calcium carbonate, with bacterial strains isolated from different ecosystem environments [42]. The strains were incubated at $37{ }^{\circ} \mathrm{C}$ for 1 week to form crystals. Colonies that showed good production of crystals, as confirmed microscopically, were selected and

Table 1 Properties of the organic soil sample

\begin{tabular}{|c|c|c|}
\hline Property & Value & Test/standard \\
\hline Liquid limit (\% w/w) & 101 & Cone penetrometer; BS $1377: 1990$ [34] \\
\hline Plastic limit (\% w/w) & 63 & BS $1377: 1990[34]$ \\
\hline Plasticity index (\% w/w) & 38 & BS $1377: 1990[34]$ \\
\hline Specific gravity, $\mathrm{G}_{\mathrm{s}}$ & 2.06 & BS EN ISO 11508:2017 [35] \\
\hline $\begin{array}{l}\text { Natural gravimetric moisture content } \\
(\% \mathrm{w} / \mathrm{w})\end{array}$ & 55.5 & BS EN ISO 17892 : Part $1: 2014$ [36] \\
\hline $\begin{array}{l}\mathrm{pH} \text { (of soil suspended in distilled } \\
\text { water) }\end{array}$ & 7.15 & BS ISO 10390:2005 [37] \\
\hline Ash content $(\% \mathrm{w} / \mathrm{w})$ & 17.7 & ASTM D2974-14 [38] \\
\hline Organic matter content $(\% \mathrm{w} / \mathrm{w})$ & 50.8 & Loss of ignition; ASTM D2974-14 [38] \\
\hline Zeta potential $(\zeta)(\mathrm{mV})$ & -38.4 & BS ISO 13099-2:2012 [39] \\
\hline $\begin{array}{l}\text { Cation exchange capacity (CEC) } \\
\quad(\mathrm{meq} / 100 \mathrm{~g} \text { soil })\end{array}$ & 72 & pH 7 ammonium acetate CEC [40] \\
\hline Colour description & $\begin{array}{r}10 \mathrm{YR} \\
3 / 2\end{array}$ & Munsell Chart \\
\hline D60 (mm) & 0.2 & $\begin{array}{l}\text { Sieving test followed by hydrometer test; } \\
\text { BS 1377:1990 [34] }\end{array}$ \\
\hline $\mathrm{D} 10$ (mm) & 0.003 & $\begin{array}{l}\text { Sieving test followed by hydrometer test; BS 1377:1990 } \\
\text { [34] }\end{array}$ \\
\hline
\end{tabular}


passaged twice on B4 plate to obtain purified single colonies. The selected strains were transferred to Nutrient Agar (Oxoid, UK) and cryogenic storage beads (Microbank®, Fisher Scientific, UK) for storage at $4{ }^{\circ} \mathrm{C}$ and $-80{ }^{\circ} \mathrm{C}$, respectively.

The selected strains were then identified using matrix-assisted laser desorption/ionisation time-of-flight/time-of-flight tandem mass spectrometry (MALDI-TOF/TOF MS) proteomicbased biotyping approach, using a Bruker Daltonics MALDI Biotyper. Mass spectrometry is an analytical technique in which samples are ionised into charged molecules and the ratios of their mass-to-charge $(\mathrm{m} / \mathrm{z})$ can be measured. In MALDI-TOF mass spectrometry, the ion source is matrix-assisted laser desorption/ionisation (MALDI), and the mass analyser is timeof-flight (TOF) analyser [43]. Microbial identification using MALDI-TOF MS is based on the principle that every microorganism has a specific protein composition, which gives its characteristic and unique mass spectra. The technique thus determines the unique proteomic fingerprint of an organism through pattern recognition, matching characteristic patterns (mass spectra) against an extensive reference library to determine the organism's identity. Continuous expansion of the reference library thus ensures that a broad range of microorganisms can be identified easily, as the quality and extent of coverage of the database of peptide mass fingerprints are the main limitation associated with the technique for successful identification of unknown samples [44, 45].

The use the technique has gained increasing popularity in the recent years as a new inexpensive, simple and accurate technique for rapid microbial identification in particular in clinical microbiology laboratories, where rapid and accurate diagnosis of microbial infections is of essence for decreased mortality and reduced length of hospitalisation [46, 47]. Extensive research works on the reliability and accuracy of the technique in the identification of clinically relevant bacteria and yeasts were conducted (see, e.g. [44-55], amongst many other). These demonstrated the sensitivity and accuracy of the technique in detecting complex molecules such as proteins, peptides, lipids and nucleic acids and concluded that the performance of MALDI-TOF MS can be comparable or superior to phenotypic methods currently in use in clinical microbiology laboratories and that it can be further improved by database updates and analysis software upgrades. For the particular equipment used in the presented study in this paper, a recent multi-centre study on a total of 4399 isolates of medically important bacteria and yeasts concluded that the equipment accurately identifies most clinically important bacteria and yeasts and has optional processing methods to further improve isolate characterisation. Overall, $98.4 \%$ of all bacterial and yeast isolates were correctly identified to the genus and species/species complex level, and $95.7 \%$ of isolates were identified with a high degree of confidence [55]. Thus, the use of the MS technique for routine identification of microbial pathogens has profoundly influenced microbiological diagnostics and is progressively replacing biochemical identification methods in clinical settings where it is now routinely used [46, 56]. The technique has also been increasingly used in the field of environmental microbiology in the recent years. Examples include the identification of microbes isolated from sewage sludge [57]; marine sponges [58]; soils contaminated with organic compounds [59]; the study of microbial diversity in hot water ponds in the Yamunotri landscape, Himalaya [60]; and its use to identify polymer producer bacteria [61]. Some studies showed however that MALDITOF MS technique may have a lower discriminatory power for strains of closely related species [62] or may incorrectly identify rare or unknown species that are not contained in the reference entries of commercial databases. For a more reliable identification, many laboratories often extend the commercial database (e.g. [56, 63]). The use of the preparatory extraction of microbes with formic acid (FA) was also reported to increase the ability of MALDI-TOF MS 
in identifying in particular Gram-positive species [43]. Therefore, the formic acid extraction method was used to prepare samples in this study. In order to ensure homogeneity and reliability of the results, six different sample spots (replicates) for each sample were prepared, to generate six combined mass spectra (MSP) per bacterial isolate. For the particular equipment used in this study, the commercial software MALDI Biotyper software 3.0 (Bruker Daltonik) by the manufacturers specifies confidence levels as simplified comparison scores ranging from 0.0 to 3.0 , where scores $\geq 2.3$ represent a confident match at the genus level, and high probability at the species level, scores between 1.7 and 2 provide a secure genus identification and probable species identification, whereas values $<1.7$ are considered as non-reliable identifications. These guidelines were used to generate species-level matches for the identification of the isolates studied, which all provided a good match, i.e. scores of $>2.0$.

\section{Chemical Analysis}

The urease activity of the microorganisms was measured in terms of ammonia production during the treatment both in the discharged liquid and the treated soil; it was assumed that the rate of urea hydrolysis would be proportional to the urease activity. All samples and controls were prepared in duplicate.

To detect the ammonia concentrations in the discharged liquid, the phenate method approved by the American Public Health Association/American Water Works Association/ Water Environment Federation) was used [64]. One unit urease activity is the amount of urease that generates $1.0 \mu \mathrm{mol}$ of ammonium per minute. The ammonium concentration ranging $0.02-2 \mathrm{mg} \mathrm{NH}_{4}+/ \mathrm{L}$ can be measured accurately with this method. However, the high concentration samples were diluted with distilled water and corrections were made in the end calculations.

For soil samples, ammonia concentration in the pore water of the treated soil was directly measured using a urease activity assay kit (colorimetric; Abcam, USA) based on a modified Berthelot method.

\section{Soil Sample Preparation and Treatment Implementation}

\section{Treatment Preparation}

For the geotechnical analyses, strains were cultivated at $\mathrm{pH} 7$ under aerobic batch conditions in a sterile culture medium of Nutrient Broth (Oxoid, UK). Incubation was performed in a shaking incubator at $200 \mathrm{rpm}$ and $37^{\circ} \mathrm{C}$. The strains were grown to an early stationary phase, i.e. optical density (OD), OD600 ranging from 0.5 to 0.7 ; they were then harvested by centrifuging at $8000 \mathrm{x} \mathrm{g}$ for $10 \mathrm{~min}$ and resuspended in sterile sodium chloride solution ( 9 $\mathrm{g} / \mathrm{L} \mathrm{NaCl}$ ) to achieve a final concentration of approximately $1 \times 10^{8} \mathrm{cfu} / \mathrm{mL}$. The same $\mathrm{NaCl}$ solution was used to obtain a second concentration of $1 \times 10^{7} \mathrm{cfu} / \mathrm{mL}$ by dilution, in order to assess the effect of bacteria population on the results.

Cementing reagents consisted of equimolar urea $\left(\mathrm{CO}(\mathrm{NH})_{2}\right)_{2}$ and calcium chloride $\left(\mathrm{CaCl}_{2}\right)$ solutions. Water or treatment solutions of $15 \%$ by dry soil mass were added for the untreated and treated samples, respectively. The selection of this amount of added water/solution is explained in Safdar et al. [30]; it corresponded to the amount of water required to keep a constant soil volume during a set of accompanying investigations that were ran in parallel, where treatments were implemented electrokinetically (see [30]). 


\section{Specimen Types}

For the parametric study carried out to identify the most suitable treatments based on the unconfined compressive strength (UCS) of the soil specimens, a number of triplicate control soil specimens and soil specimens with treatments with or without bacteria were prepared. These consisted of:

- Untreated soil specimens with their moisture content adjusted to match that of the treated soils (C2_Water), thus excluding any moisture content effects on the strength

- Soil specimens treated with Nutrient Broth solution of a $3 \mathrm{~g} / \mathrm{L}$ concentration (C3_Nutr)

- Soil specimens with Nutrient Broth and bacteria only (no cementing agents), to study the possible effects of microorganism cells on soil strength (C4_Nutr_Bl, C5_Nutr_Re, C6 Nutr_Ml, C7_Nutr_Lf)

- Specimens with Nutrient Broth and cementing reagents only, i.e. biostimulation study (Biost1_7d and Biost2_1d)

- Specimens with full treatments, i.e. Nutrient Broth, cementing reagents and bacteria, i.e. bioaugmentation study: all specimens of batches 2 and 3 in Table 2.

Note that after the first set of results presented in Safdar et al. [30] and which will be included here for the sake of completeness, it was decided to proceed with a more comprehensive parametric study based mainly on the overall best candidate strain. Bacillus licheniformis, which, in addition to showing some of the highest strengths achieved in Safdar at al. [30], also has a number of other advantages (i.e. it is widespread in natural soils, is relatively small - about $1 \mu \mathrm{m}$ in diameter-which facilitates its motility through smaller pore throats; it is facultative anaerobic, so it can survive in environmental conditions of reduced oxygen supply and is a spore-generating bacterium: this feature could be advantageous for potential self-healing of the treatments) [30]. Some, fewer, parametric study tests were also done for the second-best candidate, Lysinibacillus fusiformis, in terms of strengths achieved, which also shares many of the above additional advantages listed for Bacillus licheniformis. The list of specimens prepared for UCS testing is summarised in Table 2.

\section{Pressure Flow Column Setup}

Treatments, or water, for control specimens (C2_Water), were implemented via pressuredriven flow through a soil column. The system consisted of a transparent polymethyl methacrylate (PMMA) cylindrical mould of $50 \mathrm{~mm}$ in diameter and $170 \mathrm{~mm}$ in length, a hydraulic pump, a compression frame and a collector of the discharged liquid (Fig. 1). Note that for the parametric study presented here the soil was first mixed with the individual microorganisms, where applicable, before the addition of the treatment solutions. This was done to ensure a uniform distribution of the bacteria in the soil, thus excluding any effects of uncontrolled nonuniformity on the parametric study results. However, this implementation method would not be applicable under existing earthwork infrastructure; the study of a different implementation method to suit this field application is beyond the scope of this paper but the intention is to implement the treatments electrokinetically (EK). The feasibility of EK biocementation for different degrees of saturation was thus the focus of a parallel study using one of the successful treatment combinations, before optimisation [65]. 


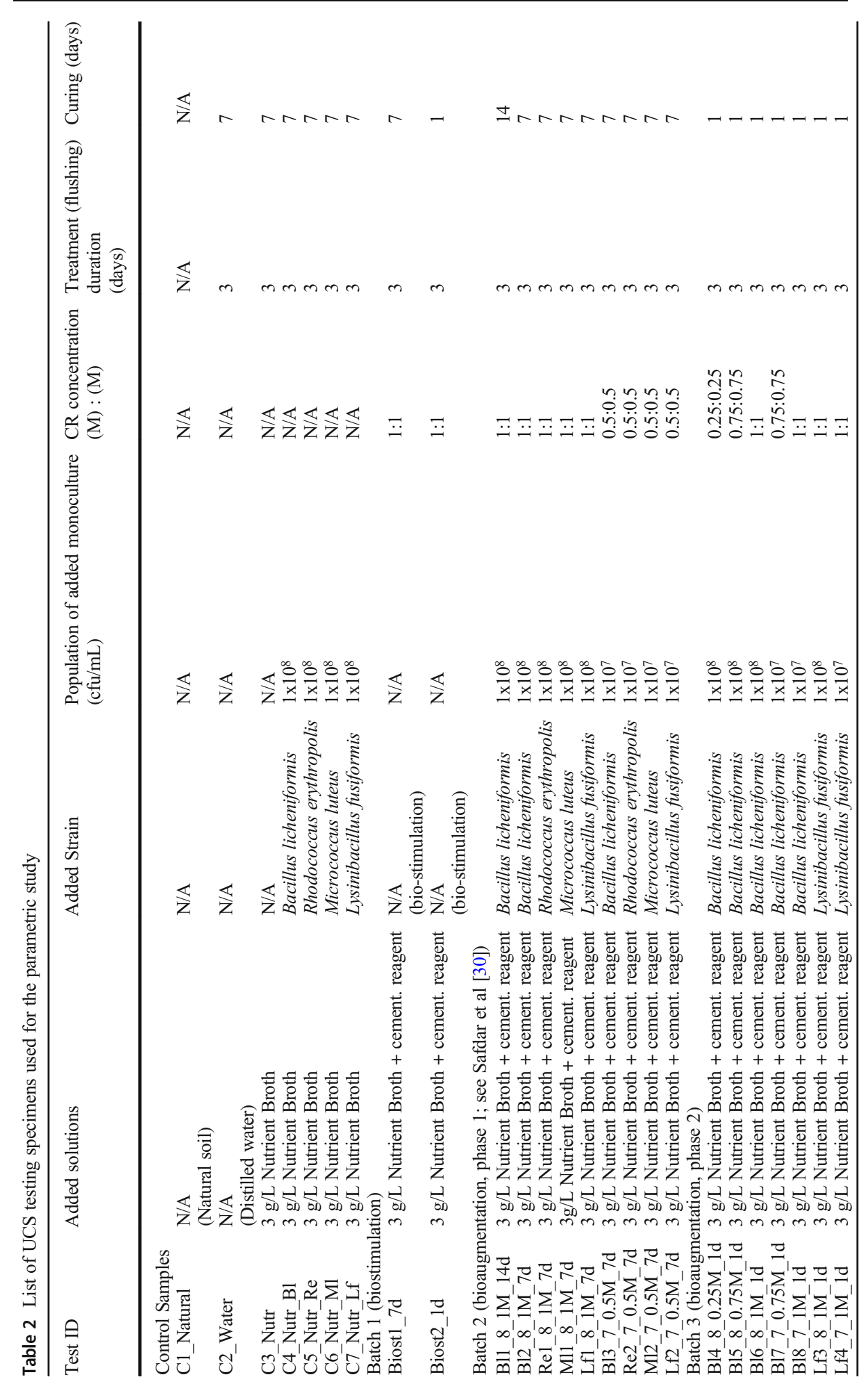




\section{Implementation Procedure}

- Mixing was performed under non-sterile conditions; i.e. the soil was not autoclaved prior to mixing with bacteria and cementation reagent solution. This was done in order to maintain the original physicochemical characteristics and nutrient content of the soil.

- After mixing, the soil was covered with air-tight seal and left for 48-72 h to attain homogeneity. Standard UCS specimens were then made from the soil sample by static compaction at a rate of $1 \mathrm{~mm} / \mathrm{min}$ to match the original field dry density of $0.919 \mathrm{~g} / \mathrm{cm}^{3}$.

- The samples were transferred into the PMMA mould, where they were sandwiched between two layers of perforated disks and filter papers, to avoid turbulent inflow and clogging at the inlet and outlet, and were mounted tightly onto the compression frame.

- The mould inlet was connected to the outlet of the pump.

- The added water or treatment solutions were supplied into the specimen mould at a constant flow pressure of $150 \mathrm{kPa}$ by regulating the pressure from the control panel of the pump and at room temperature $\left(22-27^{\circ} \mathrm{C}\right)$ during 3 days.

- For control samples C2_Water and C3_Nutr, approximately $7.5 \%$ by dry soil mass of water or Nutrient Broth, respectively, was injected under pressure, followed by another dose of $7.5 \%$ by dry soil mass of water or Nutrient Broth, respectively, after 24-28 h had elapsed.

- For control samples C4_Nutr_Bl, C5_Nutr_Re, C6_ Nutr_Ml and C7_Nutr_Lf, approximately $7.5 \%$ (by dry soil mass) of Nutrient Broth containing the bacteria was first premixed with the soil and then the rest of the Nutrient Broth (without bacteria) was injected under pressure into the soil samples after 24-28 h.

- For the biostimulation specimens, Biost1_7d and Biost_1d, first the Nutrient Broth of approximately $7.5 \%$ of dry soil mass was injected, followed by $7.5 \%$ per dry soil mass cementing reagent solution, i.e. urea and calcium chloride, all in one solution, after 24 $28 \mathrm{~h}$.

- Finally, for specimens of batches 2 and 3 (bioaugmentation tests), approximately $7.5 \%$ by dry soil mass of Nutrient Broth containing the bacteria was first pre-mixed with the soil and then after $24-28 \mathrm{~h}$, approximately $7.5 \%$ per dry soil mass of cementing agent solution, i.e. urea and calcium chloride, all in one solution was injected into the soil samples under pressure.

- Water or treatment solution addition was followed by a variable curing duration (see Table 2).

\section{Other Tests}

The $\mathrm{pH}$ and ammonium contents were monitored by sampling the discharged liquid; ammonium in the pore water of the treated soil specimens at the end of the curing period was also measured as detailed earlier. At the end of the treatment, the samples were removed from the mould and were covered again with air-tight seal and left for 48-72 $\mathrm{h}$ to attain homogeneity of treatments. Details of all procedures and justification of choices, e.g. of treatment solutions or treatment implementation pressures, can be found in Safdar et al. [30]. At the end of the UCS tests, indicative specimens of treated and untreated soils, respectively, were cut out for conventional 1-D oedometer testing and volume change measurements with Vernier callipers 


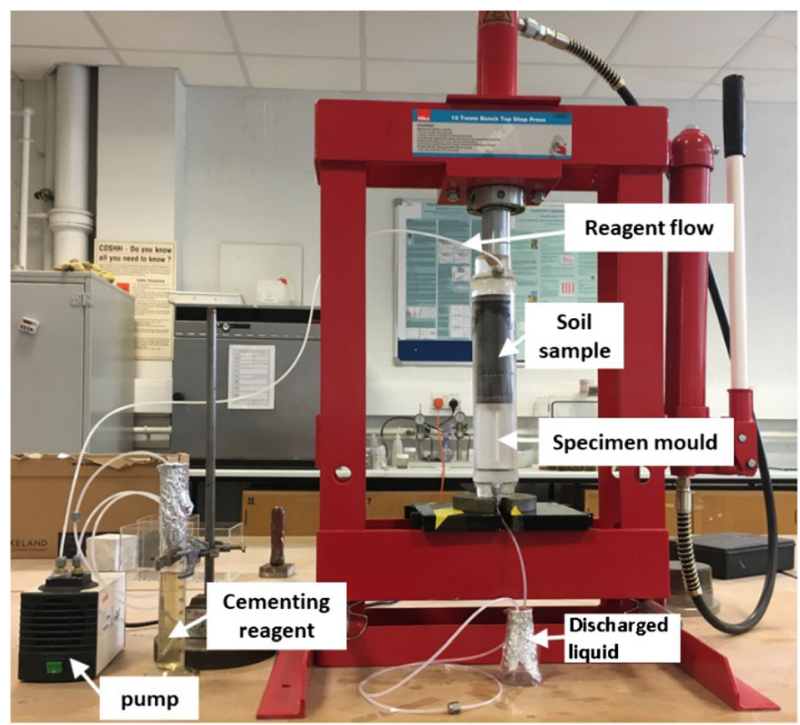

Fig. 1 Pressure flow column setup

during air-drying to assess the shrinkage of the specimens. Finally, simple respiration tests using a garden kit were performed to assess possible peat oxidation effects.

\section{Results and Discussion}

\section{Microbiological Study Results}

Four candidate strains for biocementation were selected based on their urease activity and ability to grow and survive at low to medium temperatures and $\mathrm{pH}$ values of 4.5-10. These were Bacillus licheniformis, Rhodococcus erythropolis, Micrococcus luteus and Lysinibacillus fusiformis. The American Type Culture Collection (ATCC) classifies these microorganisms as biosafety level (BSL) 1, according to the US Department of Health and Human Services [66], i.e. not known to consistently cause disease in healthy adults, and of minimal potential hazard to laboratory workers and the environment. Similarly, the BacDive database for standardised bacterial information classifies them into risk group 1 (biological agents which are unlikely to cause disease in an individual) according to the German Federal Institute for Occupational Safety and Health [67].

The urease activity of the four monocultures during the incubation period in crude enzyme is shown in Fig. 2. It can be seen that Bacillus licheniformis and Lysinibacillus fusiformis recorded the maximum urease activity at $72 \mathrm{~h}$; subsequently this either reduced or remained around the maximum value with some fluctuations, although cell population for both these strains continued to increase well after the first $72 \mathrm{~h}$. Conversely the urease activity of Micrococcus luteus and Rhodococcus erythropolis continued to increase with incubation duration. Rhodococcus erythropolis showed the lowest urease activity. 


\section{UCS Parametric Study Results}

The parametric study results will be discussed in terms of $\mathrm{UCS}$ and $\mathrm{CaCO}_{3}$ contents (based on acid digestion testing) for the specimens listed in Table 2 (see Fig. 3a and b). An increase in UCS accompanied by an increase in the $\mathrm{CaCO}_{3}$ content of the specimen would be considered as evidence that biocementation has taken place. The ammonia measurements at the end of the UCS test are also presented in Fig. $3 \mathrm{~b}$ as a black solid line to compare to $\mathrm{CaCO}_{3}$ trends, as higher urease activity hence ammonia concentrations would logically lead to higher $\mathrm{CaCO}_{3}$ precipitation. Water content measurements at the end of the test are also shown in Fig. 3c to assess any possible effects of the water content on the soil strength. The $\mathrm{pH}$ at the end of the UCS test is also presented in Fig. 3c as a black solid line. Inspecting Fig. 3c, it can be inferred that the effect of water content on the strength would be small in most cases, as water content variations were generally small for all treated samples (including the control samples with added water and/or Nutrient Broth) with few exceptions. As for the $\mathrm{pH}$ at the end of the tests, where $\mathrm{pH}$ drops following carbonate precipitation, it appears to remain slightly alkaline except in the case of the longer curing duration but generally close to the natural soil $\mathrm{pH}$ of 7.15; therefore, dissolution of $\mathrm{CaCO}_{3}$ due to soil acidity would not be expected. Samples with $0.5 \mathrm{M}$ reagent solution had the highest $\mathrm{pH}$ increase and overall the highest amount of reaction products compared to the respective $1 \mathrm{M}$ reagent solution samples. Note that in the microbiology tests it was found that the $\mathrm{CaCO}_{3}$ precipitation using the four selected microorganisms, especially Bacillus licheniformis, was optimised in the $\mathrm{pH}$ rage of 7.2 to 7.85 . This $\mathrm{pH}$ range is lower compared to other $\mathrm{CaCO}_{3}$-producing bacteria such as Sporosarcina pasteurii for which optimal pH 8.7-9.5 was reported (see, e.g. [68]). As for ammonia concentrations related to urea hydrolysis, generally they follow the trends of $\mathrm{CaCO}_{3}$ and $\mathrm{UCS}$ strength results; however, there are some notable exceptions, where the concentrations of ammonia are much higher than expected in comparison with the $\mathrm{CaCO}_{3}$ values. In addition to an indication of a possible continuing enzymatic activity, this can also be an artefact of the graphical determination of the concentrations from the ammonia calibration curve; regardless of this, and even with some allowance for this interpretation error, the observed concentrations are generally higher than the allowable limits of total ammonia $\left(\mathrm{NH}_{3}\right.$ and

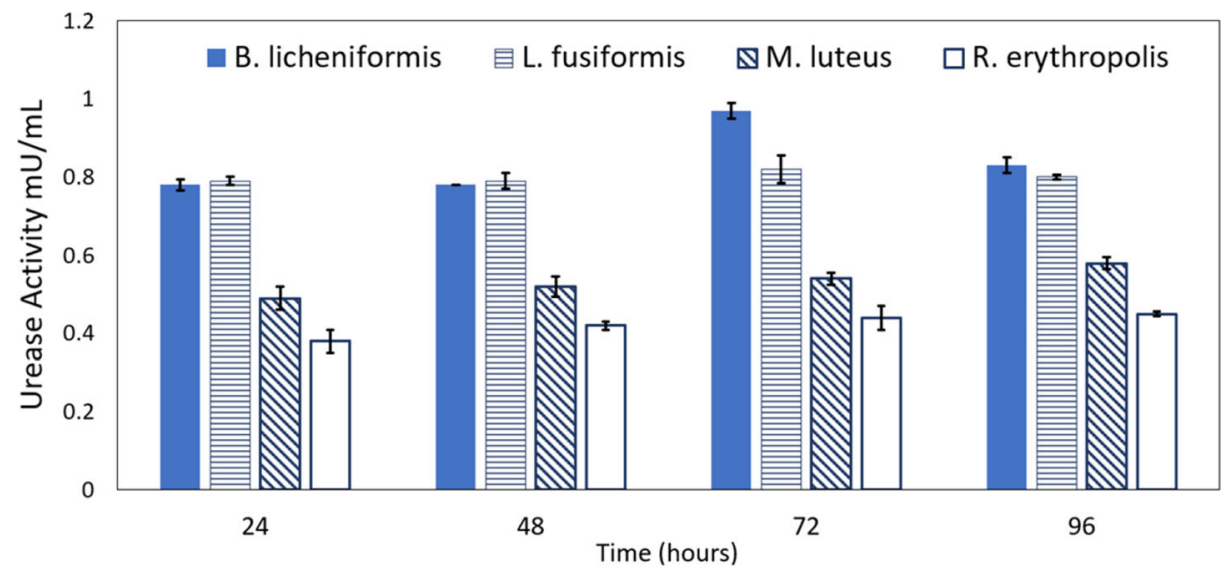

Fig. 2 Urease activity of microorganisms at different times 
$\mathrm{NH}_{4}{ }^{+}$) for drinking water according to UK legislation, set to $0.5 \mathrm{mg} / \mathrm{L}$ [69]. In most cases, reagent concentrations lower than $1 \mathrm{M}$ led to higher ammonia concentrations. This is consistent with the formation of $\mathrm{CaCO}_{3}$ and strength development observations and could be attributed to urease activity inhibition at high calcium chloride concentrations [7]. For the successful field application of this technique, there is a need to eliminate the excessive ammonia concentration. This can be done by flushing the effluent with a large quantity of water, but there is a danger of the ammonia-rich effluent to seep into the groundwater. Keykha et al. [70] recommended instead the use of natural zeolite for the $\mathrm{NH}_{4}{ }^{+}$removal from this aqueous solution. Mujah et al. [15] also suggest treatment of the effluent before discharge or the use of ammonia in fertilisers for nearby areas.

Before proceeding into assessing the parametric study results of treated specimens, the following observations can be made regarding the control specimens: firstly, it can be seen that compared to the natural soil, all the rest of the control samples had increased strengths. This included specimens with added water only (C2_Water) which showed a small increase $(8 \%)$ in strength; this cannot be explained by chemical effects, but it would more likely be the result of some density increase/consolidation effect compared to the natural soil specimens (C1_Natural). The addition of the Nutrient Broth (C3_Nutr) led to a $67.1 \%$ increase in strength compared to the natural soil; this can be explained by the effect of salt content in the Nutrient Broth, leading to particle flocculation/binding thus affecting the soil strength. Note that salts are used for soil stabilisation, which is the result of ionic charge changes; however, the soil property improvement may only be temporary, as opposed to the biocementation treatment effects. The addition of bacteria in the Nutrient Broth (without cementing reagents) led to a drop in the strength in most cases with the exception of one, where the water content of the specimens was lower, which partly explains this higher strength; this is possibly linked to the increase in organic biomass in the soil which negatively affects strength [7]. Based on these observations, the discussion on the effect of the full treatments (i.e. Nutrient Broth and cementing reagents) on soil strength and $\mathrm{CaCO}_{3}$ content will be based more appropriately in terms of differences between the latter four samples and the respective fully treated samples having the same bacteria population $\left(1 \times 10^{8} \mathrm{cfu} / \mathrm{mL}\right)$; these, together with the results of t-tests, are shown in Table 3. However, differences with respect to the Nutrient Broth only specimen are also shown for completeness on the right-hand side column of Table 3.

\section{Biostimulation Tests}

Comparing the Biost1_7d and Biost2_1d against the respective control sample, C4_ Nutr_B1, there is a definite increase in strength. However, if compared to the control sample C3_Nutr with Nutrient Broth only, the change is not significant (see Table 3); in addition, there is little increase in the $\mathrm{CaCO}_{3}$ content of the soil compared to the control sample with Nutrient Broth only. Therefore, there is no evidence of biocementation in the case of biostimulation for the applied treatment protocol. Biostimulation is however an interesting mechanism for the in situ application of biocementation under existing embankments. One potential disadvantage is that biostimulation is a lengthier process compared to bioaugmentation [71]; this would increase the duration of the EK implementation leading to higher costs and power consumption, thus potentially reducing the sustainability of the biocementation treatment. The application of a different biostimulation treatment protocol and treatment duration will be revisited in future work. 

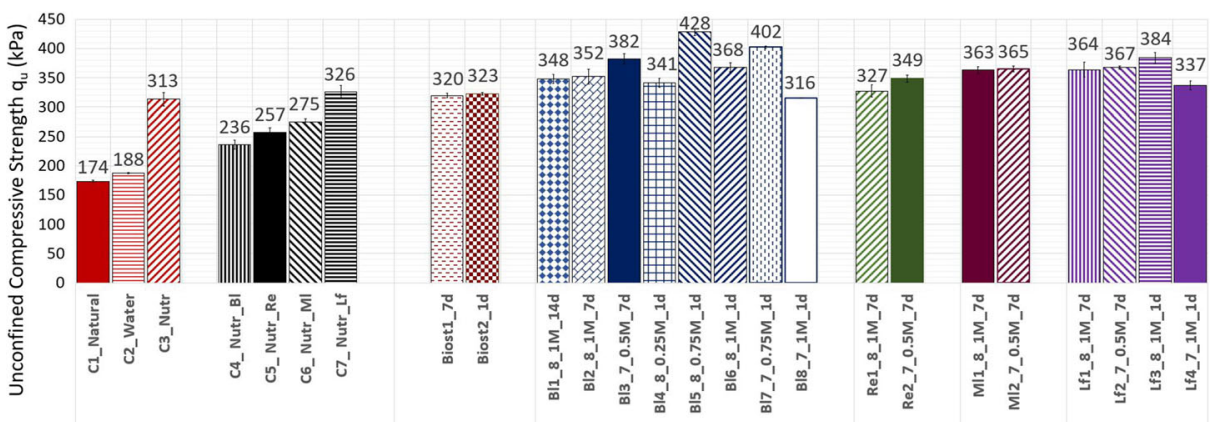

(a)

R. erythropolis M. luteus

L. fusiformis

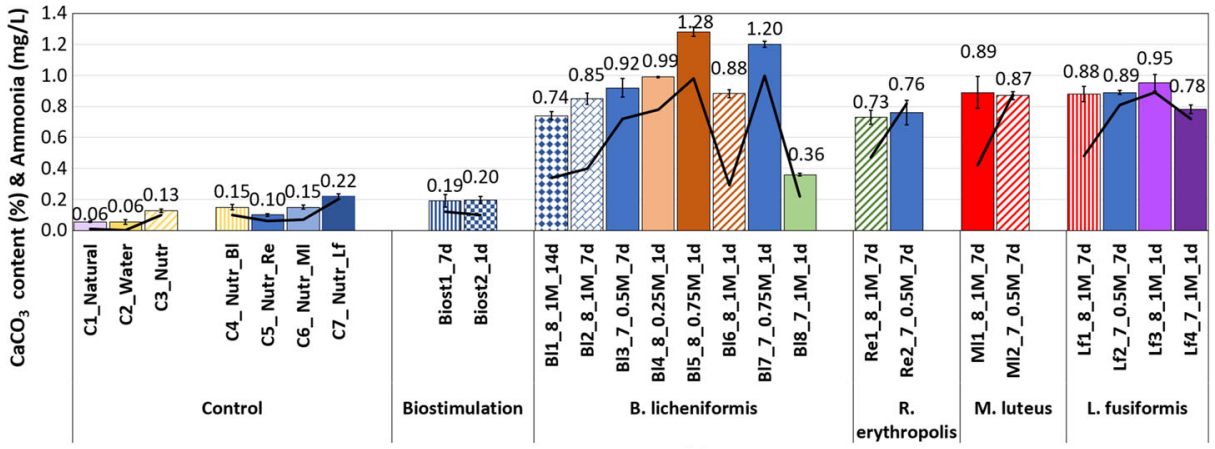

(b)

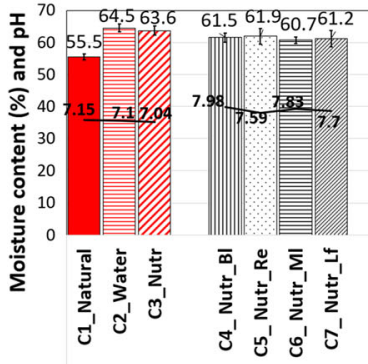

Control

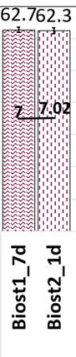

Biostimulation

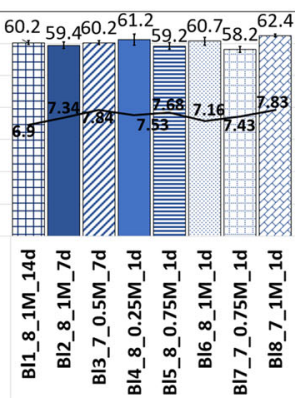

B. licheniformis

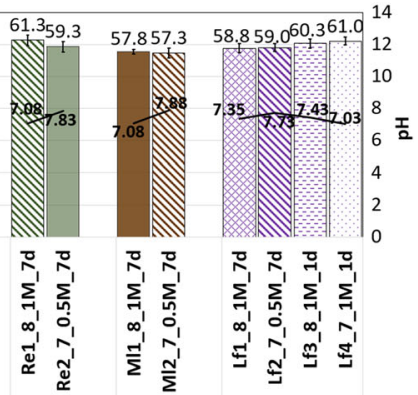

R. erythropolisM. luteus L. fusiformis

(c)

Fig. 3 Summary of a unconfined compressive strength testing results; $\mathbf{b}$ end-of-test $\mathrm{CaCO}_{3}$ and ammonia measurements (solid black line); c end-of-test moisture content and $\mathrm{pH}$ (solid black line)

\section{Effect of Bacteria Population}

For the two populations tested, differing by one order of magnitude, it can be seen that strengths and $\mathrm{CaCO}_{3}$ contents were generally higher for the $10^{8} \mathrm{cfu} / \mathrm{mL}$, all other parameters being equal, but the differences are rather small. Higher differences in population could be tried for more considerable differences to identify optimal concentrations. 


\section{Effect of Curing Time}

Comparing the $B$. licheniformis results B11_8_1M_14d, B12_8_1M_7d and B16_8_1M_1d of the same mix cured for different time periods of 14 days, 7 days and 1 day, respectively, there is a trend of increasing strength and $\mathrm{CaCO}_{3}$ content as curing time decreases. The same trend of strength increase with reduced curing time is noted for L. fusiformis results Lf1_8_1M_7d and Lf1_8_1M_1d of the same mix cured for 7 and 1 day, respectively. Although the differences in strength are small for any firm conclusions, the trends are consistent and concur with findings from the literature, for instance, Almajed [72], who biocemented sands using enzymatically induced calcite precipitation. This could be attributed to loss of enzymatic activity due to ammonia by-product effects. On the other hand, $\mathrm{pH}$ measurements indicated that the $\mathrm{pH}$ at the end of the tests was neutral to slightly alkaline for all tests conducted with 1day or 7-day curing; for 14-day curing slightly acidic conditions developed, i.e. a $\mathrm{pH}$ of 6.9 which is however not low enough for dissolution of $\mathrm{CaCO}_{3}$ to begin, and lead to a decrease in strength. Note that $\mathrm{NH}_{4}{ }^{+}$, if left in soil, can be oxidised by indigenous nitrifying bacteria to produce dilute nitric acid, which will dissolve $\mathrm{CaCO}_{3}$.

\section{Effect of Solution Molarity}

Comparing B16_8_1M_1d vs. B15_8_0.75M_1d; B17_7_0.75M_1d vs. B18_7_1M_1d and Lf2_7_0.5M_7d vs. Lf4_7_1M_1d, it can be seen that the solutions of molarities between $0.5 \mathrm{M}$ and $0.75 \mathrm{M}$ performed better than the $1 \mathrm{M}$ solutions. This is also implied from the results of $\mathrm{B} 13 \_7 \_0.5 \mathrm{M} \_7 \mathrm{~d}, \mathrm{Re} 2{ }_{-}{ }_{-} 0.5 \mathrm{M} \_7 \mathrm{~d}, \mathrm{M} 12 \_7 \_0.5 \mathrm{M} \_7 \mathrm{~d}$ and Lf2_7_0.5M_7d which, although of lower bacterial population, they showed higher strengths (or slightly higher) than the samples of $1 \mathrm{M}$ reagent solution of a higher bacterial population $\left(\mathrm{Bl} 28_{-} 1 \mathrm{M} \_7 \mathrm{~d}, \mathrm{Re} 1 \_8 \_1 \mathrm{M} \_7 \mathrm{~d}, \mathrm{Ml1} \_8 \_1 \mathrm{M} \_7 \mathrm{~d}\right.$ and Lf1_8_1M_7d, respectively). These findings concur with the literature (e.g. [73] or [74] - using different bacteria). Whiffin [7] attributed this to the urease activity inhibition at higher calcium chloride, whereas Mujah et al. [15] justified this as the result of the faster calcium carbonate precipitation in solutions of higher concentration causing random, nonhomogeneous crystal distribution, unlike lower concentrations of cementation solution. It should also be noted that sample B14_8_0.25M_1d, although of lower strength than B16_8_1M_1d and B15_8_0.75M_1d, it still had a statistically significant increase in strength compared to the control sample C4_ Nutr_Bl.

\section{Performance of Different Monocultures}

From Fig. 3a and b, it can be seen that the best two results came from samples inoculated with B. licheniformis, and in the third place a L. fusiformis-inoculated soil sample. For the latter one, the results are for a $1 \mathrm{M}$ reagent concentration; tests with lower molarities at the higher bacteria population for 1 day of curing were not performed. It is notable that the $1 \mathrm{M}$ reagent solution samples inoculated with L. fusiformis as well as M. luteus had higher strengths than the respective $1 \mathrm{M}$ reagent solution samples of $B$. licheniformis. It is therefore possible that these two monocultures could have performed even better with a lower molarity cementing reagent, as discussed earlier. This can be assessed in further work. $R$. erythropolis performed 
Table 3 Summary of unconfined compressive strength changes of treated samples

\begin{tabular}{|c|c|c|c|}
\hline Sample ID & & $\begin{array}{l}\text { Control: Nutrient } \\
\text { Broth + bacteria }\end{array}$ & $\begin{array}{l}\text { Control: Nutrient Broth } \\
\mathrm{q}_{\mathrm{u}}=313.43(\mathrm{kPa})\end{array}$ \\
\hline Control: C4_Nutr_Bl & $\mathrm{q}_{\mathrm{u}}(\mathrm{kPa})$ & 236.4 & - \\
\hline \multirow[t]{3}{*}{$B l 1 \_8 \_1 M_{-} \overline{14 d}$} & $\mathrm{q}_{\mathrm{u}}(\mathrm{kPa})$ & 348.29 & 348.29 \\
\hline & $\Delta \mathrm{q}_{\mathrm{u}}(\%)$ & 47.33 & 11.12 \\
\hline & $\mathrm{p}$ value & 0.004078 & 0.09054 \\
\hline \multirow[t]{3}{*}{ Bl2_8_1M_7d } & $\mathrm{q}_{\mathrm{u}}(\mathrm{kPa})$ & 351.93 & 351.93 \\
\hline & $\Delta \mathrm{q}_{\mathrm{u}}(\%)$ & 48.87 & 12.29 \\
\hline & $\mathrm{p}$ value & 0.003541 & 0.09231 \\
\hline \multirow[t]{3}{*}{ B14_8_0.25M_1d } & $\mathrm{q}_{\mathrm{u}}(\mathrm{kPa})$ & 340.92 & 340.92 \\
\hline & $\Delta \mathrm{q}_{\mathrm{u}}(\%)$ & 44.21 & 8.78 \\
\hline & $\mathrm{p}$ value & 0.004156 & 0.1462 \\
\hline \multirow[t]{3}{*}{ B15_8_0.75M_1d } & $\mathrm{q}_{\mathrm{u}}(\mathrm{kPa})$ & 428.43 & 428.43 \\
\hline & $\Delta q_{u}(\%)$ & 81.23 & 36.7 \\
\hline & $\mathrm{p}$ value & 0.0003276 & 0.004065 \\
\hline \multirow[t]{3}{*}{ Bl6_8_IM_ld } & $\mathrm{q}_{\mathrm{u}}(\mathrm{kPa})$ & 367.73 & 367.73 \\
\hline & $\Delta \mathrm{q}_{\mathrm{u}}(\%)$ & 55.55 & 17.32 \\
\hline & $\mathrm{p}$ value & 0.00007397 & 0.02189 \\
\hline \multirow[t]{3}{*}{ B13_7_0.5M_7d } & $\mathrm{q}_{\mathrm{u}}(\mathrm{kPa})$ & N/A & 381.97 \\
\hline & $\Delta \mathrm{q}_{\mathrm{u}}(\%)$ & & 21.9 \\
\hline & $\mathrm{p}$ value & & 0.01146 \\
\hline \multirow[t]{3}{*}{ B17_7_0.75M_1d } & $\mathrm{q}_{\mathrm{u}}(\mathrm{kPa})$ & N/A & 402.10 \\
\hline & $\Delta \mathrm{q}_{\mathrm{u}}(\%)$ & & 28.29 \\
\hline & $\mathrm{p}$ value & & 0.01447 \\
\hline \multirow[t]{3}{*}{ Bl8_7_1M_1d } & $\mathrm{q}_{\mathrm{u}}(\mathrm{kPa})$ & N/A & 315.67 \\
\hline & $\Delta \mathrm{q}_{\mathrm{u}}(\%)$ & & 0.7 \\
\hline & $\mathrm{p}$ value & & 0.8669 \\
\hline Control : C5_Nutr_Re & $\mathrm{q}_{\mathrm{u}}(\mathrm{kPa})$ & 256.85 & - \\
\hline \multirow[t]{3}{*}{ Re1_8_1M_7d } & $\mathrm{q}_{\mathrm{u}}(\mathrm{kPa})$ & 327.21 & 327.21 \\
\hline & $\Delta \mathrm{q}_{\mathrm{u}}(\%)$ & 24.53 & 4.41 \\
\hline & $\mathrm{p}$ value & 0.007281 & 0.4322 \\
\hline \multirow[t]{3}{*}{ Re2_7_0.5M_7d } & $\mathrm{q}_{\mathrm{u}}(\mathrm{kPa})$ & N/A & 348.75 \\
\hline & $\Delta \mathrm{q}_{\mathrm{u}}(\%)$ & & 11.28 \\
\hline & $\mathrm{p}$ value & & 0.07646 \\
\hline Control: C6_Nutr_Ml & $\mathrm{q}_{\mathrm{u}}(\mathrm{kPa})$ & 275.49 & - \\
\hline \multirow[t]{3}{*}{$M l 1 \_8 \_1 M \_\overline{7} d$} & $\mathrm{q}_{\mathrm{u}}(\mathrm{kPa})$ & 363.12 & 363.12 \\
\hline & $\Delta \mathrm{q}_{\mathrm{u}}(\%)$ & 31.81 & 15.87 \\
\hline & $\mathrm{p}$ value & 0.0004552 & 0.0331 \\
\hline \multirow[t]{3}{*}{ Ml2_7_0.5M_7d } & $\mathrm{q}_{\mathrm{u}}(\mathrm{kPa})$ & N/A & 364.785 \\
\hline & $\Delta \mathrm{q}_{\mathrm{u}}(\%)$ & & 16.4 \\
\hline & $\mathrm{p}$ value & & 0.02917 \\
\hline Control: C7_Nutr_Lf & $\mathrm{q}_{\mathrm{u}}(\mathrm{kPa})$ & 325.53 & - \\
\hline \multirow[t]{3}{*}{$L f 1 \_8 \_1 M \_\overline{7} d$} & $\mathrm{q}_{\mathrm{u}}(\mathrm{kPa})$ & 363.57 & 363.57 \\
\hline & $\Delta \mathrm{q}_{\mathrm{u}}(\%)$ & 11.69 & 16.01 \\
\hline & $\mathrm{p}$ value & 0.09133 & 0.04562 \\
\hline \multirow[t]{3}{*}{$L f 3 \_8 \_1 M \_1 d$} & $\mathrm{q}_{\mathrm{u}}(\mathrm{kPa})$ & 384.13 & 384.13 \\
\hline & $\Delta \mathrm{q}_{\mathrm{u}}(\%)$ & 18 & 22.56 \\
\hline & $\mathrm{p}$ value & 0.01384 & 0.008202 \\
\hline \multirow[t]{3}{*}{$\mathrm{Lf} 2 \_7$-0.5M_7d } & $\mathrm{q}_{\mathrm{u}}(\mathrm{kPa})$ & N/A & 367.37 \\
\hline & $\Delta \mathrm{q}_{\mathrm{u}}(\%)$ & & 17.22 \\
\hline & $\mathrm{p}$ value & & 0.03885 \\
\hline \multirow[t]{3}{*}{ Lf4_7_1M_1d } & $\mathrm{q}_{\mathrm{u}}(\mathrm{kPa})$ & N/A & 337.06 \\
\hline & $\Delta \mathrm{q}_{\mathrm{u}}(\%)$ & & 7.54 \\
\hline & $\mathrm{p}$ value & & 0.1742 \\
\hline
\end{tabular}


less well than the other monocultures, yet, compared to the respective control sample with Nutrient Broth and bacteria (C5_Nutr_Re), the strength increases were significant ( $\mathrm{p}$ value = 0.007281 based on t-test results shown in Table 3).

\section{Stress-Strain Behaviour}

Figure 4 shows the stress-strain behaviour of indicative specimens during UCS testing. These are the untreated soil specimen and specimens of the two best-performing monocultures in terms of UCS strengths achieved, namely, B. licheniformis and L. fusiformis, respectively. The two bacteria-treated specimens showed typical characteristics of cemented soils; i.e. some strain softening after the peak strengths. These were achieved at lower strains compared to the range of strains of $2.5-3 \%$ vs $3.5 \%$, where the untreated specimen had reached its maximum strength. This is consistent with an increased stiffness of the treated specimens. It is interesting however that the strain softening is quite mild and does not resemble the very abrupt loss of strength at even smaller strains, usually noted in specimens treated with conventional cement. Although this is partly due to the fact that in this research light-to-moderate degrees of cementation were targeted, i.e. $\mathrm{CaCO}_{3}$ contents of $1-1.3 \%$ [11], overall the observed less brittle behaviour of biocemented soils compared to soils cemented with conventional OPC cement is advantageous as a very brittle behaviour with sudden loss in strength within relatively small strain ranges is not desirable.

\section{Treatment Uniformity}

A common challenge reported by researchers is the uniformity of the biocementation treatments in terms of $\mathrm{CaCO}_{3}$ distribution (see, e.g. [9, 75]). For this reason, the uniformity of the treatments was continuously investigated by measuring $\mathrm{CaCO}_{3}$ contents at different levels of the specimens after testing. Figure 5 shows indicative results of $\mathrm{CaCO}_{3}$ contents measured at different height levels of the specimens, i.e. top, middle and bottom. From the figure, it can be seen that most specimens had a uniformly

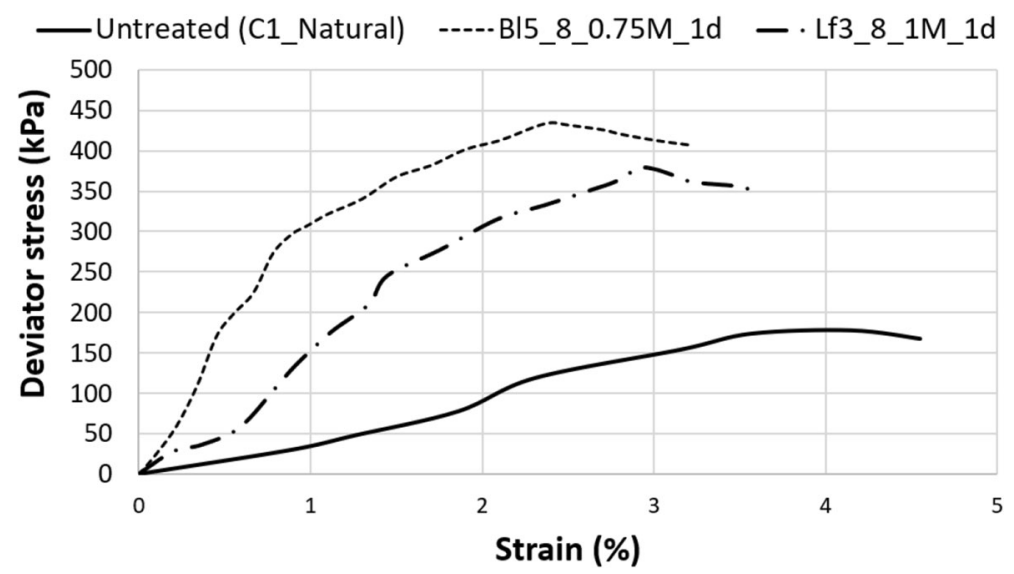

Fig. 4 Indicative stress-strain results of untreated and treated specimens 


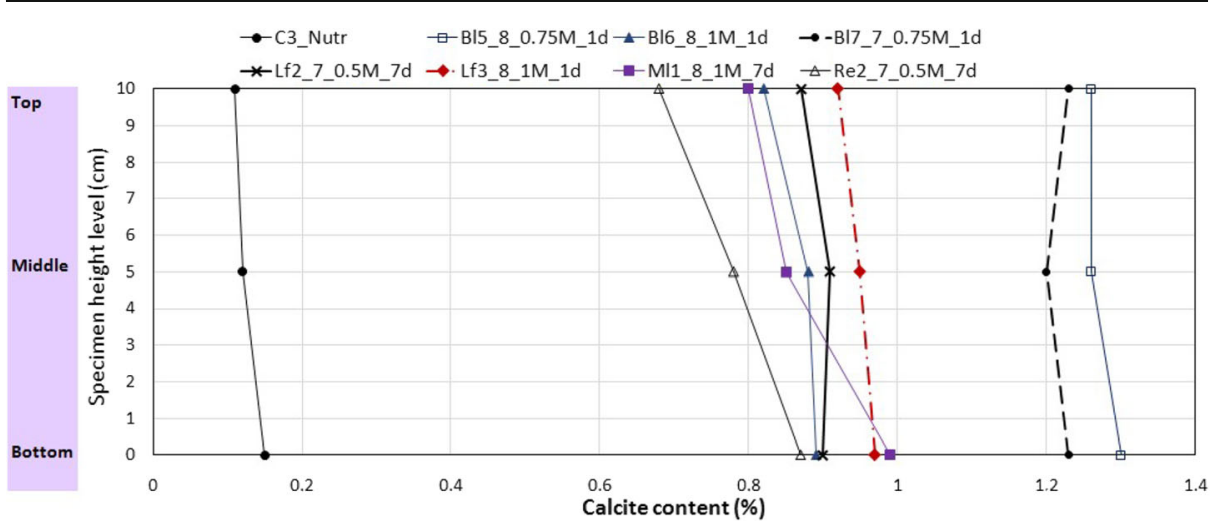

Fig. $5 \mathrm{CaCO}_{3}$ distribution along the height of treated samples

distributed $\mathrm{CaCO}_{3}$ along their height. This indicates that the provision of two layers of perforated disks and filter papers was effective in distributing the treatment solutions uniformly, avoiding turbulent inflow and clogging at the inlet and outlet. The uniform distribution of the precipitated $\mathrm{CaCO}_{3}$ in the treated samples can be considered as a result of an even distribution of bacteria in the soil. Although in this case the bacteria were premixed with the soil to achieve a uniform distribution, the application of a $150 \mathrm{kPa}$ pressure could cause bacteria to move through the soil, depending on their size compared to that of the pore throats. Indeed, in most specimens, the lower concentrations were at the top of the specimen, implying some possible migration of the bacteria, increasing their concentration towards the bottom layers, hence the calcite concentration. Interestingly, the increase in calcite content with depth is shown to be more pronounced for $M$. luteus and $R$. erythropolis, i.e. the two bacteria whose shape is not elongated, unlike B. licheniformis and L. fusiformis, whose elongated, rod-shaped cells make it difficult to flush them out during the application of pressure. Note that according to $\mathrm{Ng}$ et al. [74] varying the flow pressure could result in different quantities of precipitated $\mathrm{CaCO}_{3}$ and consequently soil strength. However, in this study, the pressure was kept constant for all experiments, to reduce the number of variables. This aspect merits further research.

\section{Discussion of the UCS Testing Results}

The presented results in terms of strength and $\mathrm{CaCO}_{3}$ precipitation all showed significant improvements compared to the control mix, although perhaps not as high as in other published literature on sands. However, as noted in Safdar et al. [30], the relationship between strength gain and $\mathrm{CaCO}_{3}$ content is soil dependent and it would be difficult to compare to the literature, referring mostly on sand bio-cementation. Also, the majority of other works repeated the treatments in multiple flushes over several days, in an attempt to achieve higher calcite precipitation levels and degrees of biocementation. Still, for the levels of $\mathrm{CaCO}_{3}$ content obtained here, the UCS strength gains are similar to [5] showing UCS of 120-200 kPa for biocemented sand with calcium carbonate contents between 0.8 and $1.33 \%$. Conversely, for the peat soil in $[22,23]$ strength gains were modest, although 16-20\% $\mathrm{CaCO}_{3}$ contents were obtained after multiple treatments. Canakci et al. [23] 
explained the lower strengths of biocemented organic soils in comparison to sands as follows: failure of a sand sample would occur either through strong calcite or sand particles, whereas for an organic soil, failure occurs through weak organic particles or bonds between strong calcite and weak organic soil particles; the latter thus govern the strength of biocemented organic soil. This is reflected in the lower measured strengths in treated organic soil compared to the sand soils of similar amounts of calcite. It should also be recalled that, as mentioned in the 'Introduction' section, organic matter can inhibit calcium carbonate precipitation and crystal growth, which could explain the lower $\mathrm{CaCO}_{3}$ percentages in the presented study.

\section{Oedometer and Air-Drying Shrinkage Results}

Indicative oedometer test results are shown in Fig. 6, for the untreated soil versus the soil treated with $1 \times 10^{8} \mathrm{cfu} / \mathrm{mL}$ Bacillus licheniformis with cementing reagent solution of $1 \mathrm{M}$ under 1-D compression. Note that before the oedometric compression loading in stages, the two specimens were left to swell (free swelling). An approximate $40 \%$ decrease in the swelling strain of the treated specimen was observed (i.e. $3.47 \%$ vs $5.76 \%$ swelling for the untreated soil) indicating the beneficial effect of the biocementation treatment for the volume change of the soil during wetting. Based on the results, the volumetric strains of the treated soil upon 1-D compression reduced by $32-47 \%$ compared to the untreated soil. Consistently with this, the coefficient of volume compressibility $\mathrm{m}_{\mathrm{v}}$ of the treated soil decreased except for the $400-800 \mathrm{kPa}$ where the $\mathrm{m}_{\mathrm{v}}$ is slightly higher for the treated soil, which could be a result of the yielding of the cementation bonds. However, $\mathrm{m}_{\mathrm{v}}$ remained of the same order of magnitude as the untreated soil, as the treated specimen was only lightly cemented. Despite this, the presented one-dimensional compressibility results showed overall a clear improvement in terms of increased stiffness of the treated soil for a wide range of stresses, unlike the only other published results of one-dimensional compressibility of a biocemented peat soil, to the authors' knowledge [23]. In the latter study, the observable reduction in the compressibility due to biocementation was up to about $50 \mathrm{kPa}$ effective stress, after which little or no difference was observed in the behaviour of the treated soil compared to the untreated soil.

The secondary compression index $\mathrm{C}_{\mathrm{a}}$, based on the processing of the results of settlement vs. time was also determined using the 'logt' method; this is linked to the long-term settlement of the soil under different levels of constant pressure. Where it was possible to identify a secondary compression branch in the treated soil settlement-time (logt) plots, i.e. in the range of $0-100 \mathrm{kPa}$, the coefficient $\mathrm{C}_{\mathrm{a}}$ of the biocemented soil settlement due to secondary compression reduced by up to an order of magnitude. Namely, $\mathrm{C}_{\mathrm{a}}(\%)$ of the untreated soil was, respectively, $0.13 \%, 0.12 \%$ and $0.39 \%$ for $0-25 \mathrm{kPa}, 25-50 \mathrm{kPa}$ and $50-100 \mathrm{kPa}$ pressures vs. $0.04 \%, 0.02 \%$ and $0.15 \%$ for the treated soil. Beyond these pressure ranges, secondary compression did not appear to occur for the biocemented specimen for the duration of the test (8 days), as opposed to the untreated specimen.

For the same soil types as those tested in the oedometer, a second set of samples were also made and left to air-dry starting from their natural water content, while the volume change due to shrinkage was measured using callipers. A $16 \%$ reduction in the shrinkage of the treated specimen was recorded compared to that of the untreated specimen for the range of water contents tested, i.e. $55-33 \%$. 


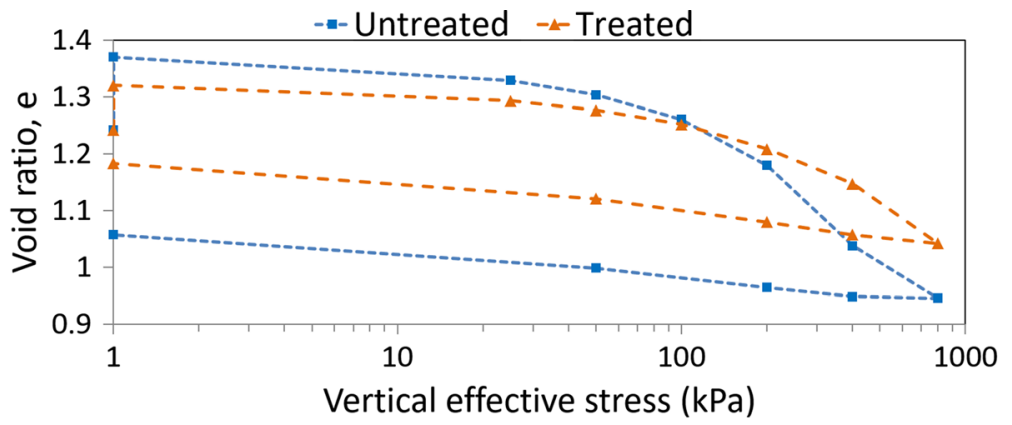

(a)

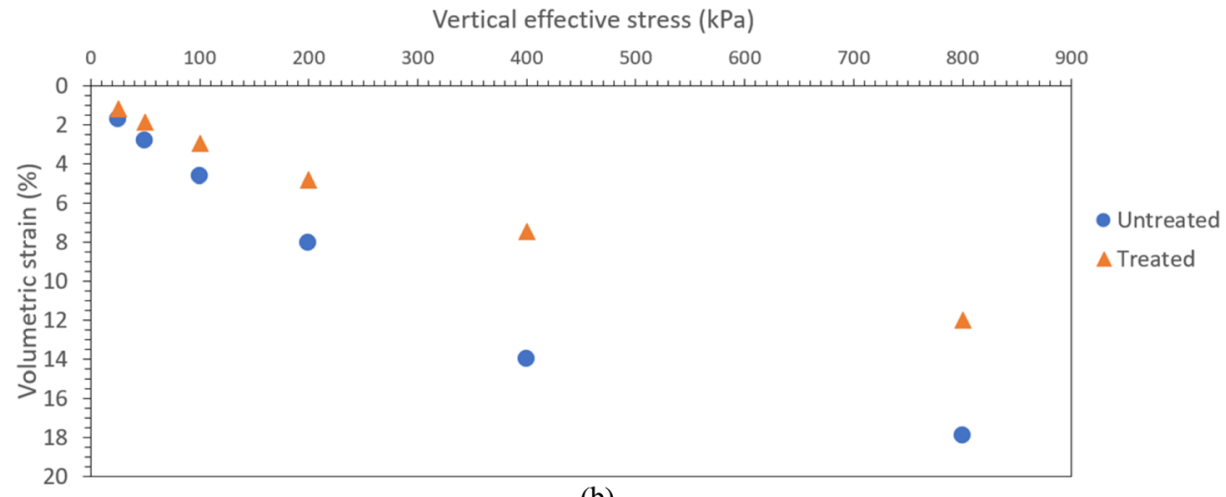

(b)

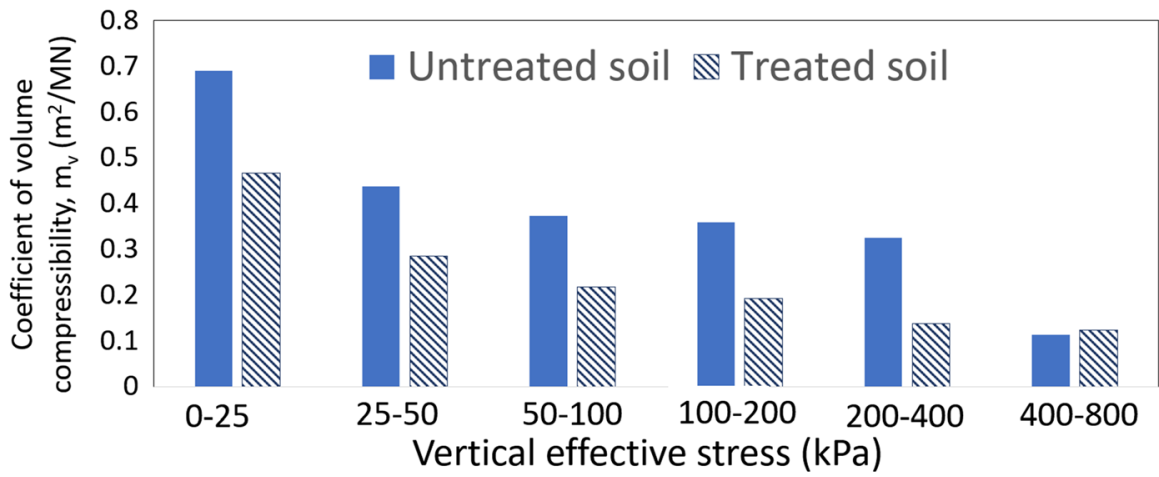

(c)

Fig. 6 One-dimensional compression results of untreated and treated specimens: a void ratio vs. vertical effective stress; b volumetric strain vs. vertical effective stress; $\mathbf{c}$ coefficient of volume compressibility $\mathrm{m}_{\mathrm{v}}$ at different effective stress levels

\section{Respiration Test}

A simple respiration test was carried out on the untreated soil, using a $\mathrm{CO}_{2}$ indicator liquid with a colour change reference chart. The moist soil was placed in a sealed container with the indicator inside and left for $24 \mathrm{~h}$. Interestingly, there was no colour change of the 
indicator after this time. Therefore, the sample was left in the container for a week but again no colour change was observed. No change of colour was observed in the treated samples either. This suggests that there was little biological activity in the native soil, presumably as the soil was already humified; from this it can be inferred that volume change due to oxidation is not likely to be a major cause of settlements for this layer of the in situ soil. For other peat layers however, with lower degrees of humification, this mechanism could be involved; therefore, biocementation of different peat layers will be also verified in future research.

\section{Conclusions}

The aim of this work was to perform a parametric study to determine suitable biocementation treatments for an organic soil from the UK railway network using indigenous ureolytic strains and to verify at laboratory scale whether biocementation can reduce the settlement of this soil considering four possible settlement mechanisms, namely, oxidation, consolidation, secondary compression and shrinkage upon drying. The parametric study results in terms of UCS and $\mathrm{CaCO}_{3}$ content showed that samples inoculated with Bacillus licheniformis had generally higher strengths compared to those inoculated with other monocultures and that $0.5 \mathrm{M}$ and $0.75 \mathrm{M}$ solutions resulted in higher strengths compared to $1 \mathrm{M}$ solutions. Depending on the treatments used, biocementation led to a $18-81 \%$ increase in unconfined compressive strength compared to that of control samples and to $\mathrm{CaCO}_{3}$ concentrations in the region of ca. $0.7-$ $1.3 \%$. For selected treatments with $B$. licheniformis, measurements of shrinkage upon drying showed a $16 \%$ reduction in the volume change for the range of water contents tested (55$33 \%$ ), while the volumetric strains of the treated soil upon 1-D compression reduced by $32-$ $47 \%$ compared to the untreated soil; this was reflected in the values of the coefficient of volume compressibility and the coefficient of secondary compression. As far as oxidation of the soil was concerned, simple respiration tests did not indicate that this is a dominant mechanism of settlement for this soil layer; this can be justified by the state of the soil layer, which is already humified. Overall, the results proved the ability of biocementation to improve considerably the mechanical properties of the organic soil layer, even for a light degree of cementation, considering the $\mathrm{CaCO}_{3}$ contents obtained; this is promising for addressing the settlement problems of this soil. To complete the research however, different peat layers need to be tested and further optimisation of the treatments made, to increase the degree of cementation in order to further stiffen the compressible soil matrix thus minimising settlements. Succeeding in doing this will be of major interest for the railway infrastructure owners, who are seeking new, cost-effective and potentially more sustainable ground improvement techniques, of paramount importance for this type of works. Stabilising successfully the organic soil by biocementation would result in considerable financial savings on a yearly basis by greatly reducing the ongoing maintenance required and associated emergency and temporary speed restrictions, causing significant delays and placing high demand on local track maintenance resources.

Acknowledgements The authors would like to acknowledge the financial contribution of Network Rail Ltd for this project under research contracts NR-ANG-00164 and ecm_18210_ANG. 
Authors' Contributions M.U. Safdar: Experimental methodology and investigation, data curation and analysis, writing - review. M. Mavroulidou: Conceptualisation, methodology, funding acquisition, supervision, data analysis, visualisation, writing — original draft, review and editing. M.J. Gunn: Conceptualisation, methodology, supervision, writing - review and editing. D. Purchase: Methodology and supervision (microbiological study), writing - review and editing. C Gray: Experimental methodology and investigation, data curation. I. Payne: Resources, funding acquisition, conceptualisation, supervision. J. Garelick: Resources, funding acquisition, conceptualisation, supervision.

Data Availability The authors' team declare that all data and materials comply with field standards.

Code Availability Not applicable.

\section{Declarations}

Consent for Publication The authors give consent for the manuscript to be published.

Conflict of interest There authors declare that there is no conflict of interest.

Disclosure Parts of the data were originally presented at the $6^{\text {th }}$ International Symposium on Green Chemistry, Sustainable Development and Circular Economy, September 20-23, 2020, Thessaloniki, Greece.

Open Access This article is licensed under a Creative Commons Attribution 4.0 International License, which permits use, sharing, adaptation, distribution and reproduction in any medium or format, as long as you give appropriate credit to the original author(s) and the source, provide a link to the Creative Commons licence, and indicate if changes were made. The images or other third party material in this article are included in the article's Creative Commons licence, unless indicated otherwise in a credit line to the material. If material is not included in the article's Creative Commons licence and your intended use is not permitted by statutory regulation or exceeds the permitted use, you will need to obtain permission directly from the copyright holder. To view a copy of this licence, visit http://creativecommons.org/licenses/by/4.0/.

\section{References}

1. Hobbs NB (1986) Mire morphology and the properties and behaviour of some British and foreign peats. Q J Eng Geol 19:7-80

2. DeJong JT, Soga K, Kavazanjian E et al (2013) Biogeochemical processes and geotechnical applications: progress, opportunities and challenges. Géotechnique 63(4):287-301. https://doi.org/10.1680/geot.SIP13.P. 017

3. Karol RH (2003) Chemical grouting and soil stabilization, 3rd edn. Marcel Dekker, New York

4. Venda Oliveira PJ, Rosa JAO (2020) Confined and unconfined behavior of a silty sand improved by the enzymatic biocementation method. Transp Geotech 24:100400. https://doi.org/10.1016/j.trgeo.2020.100400

5. Duraisamy Y (2016) Strength and stiffness improvement of bio-cemented Sydney sand. PhD thesis, University of Sydney. Available from: http:/hdl.handle.net/2123/15533. Accessed 1 July 2021

6. Hammes F, Boon N, de Villiers J, Verstraete W, Siciliano SD (2003) Strain-specific ureolytic microbial calcium carbonate precipitation applied and. Environ Microbiol 69(8):4901-4909

7. Whiffin VS (2004) Microbial $\mathrm{CaCO}_{3}$ Precipitation for the production of biocement, $\mathrm{PhD}$ thesis, Murdoch University, Perth, Western Australia. Available from: https://researchrepository.murdoch.edu.au/id/eprint/ 399/2/02Whole.pdf. Accessed 1 July 2021

8. Al-Thawadi SM (2008) High strength in-situ biocementation of soil by calcite precipitating locally isolated ureolytic bacteria, $\mathrm{PhD}$ thesis, Murdoch University, Perth, Western Australia. Available from: https:// researchrepository.murdoch.edu.au/id/eprint/721/. Accessed 1 July 2021

9. Al Qabany A, Soga K, Santamarina C (2012) Factors affecting efficiency of microbially induced calcite precipitation. J Geotech Geoenviron 138(8):992-1001. https://doi.org/10.1061/(ASCE)GT.1943-5606. 0000666

10. Montoya BM, DeJong JT, Boulanger RW (2013) Dynamic response of liquefiable sand improved by microbial induced calcite precipitation. Géotechnique 63(4):302-312 
11. Montoya B, DeJong J (2015) Stress-strain behavior of sands cemented by microbially induced calcite precipitation. J Geotech Geoenviron 141(6):04015019

12. Gao Y, Hang L, He J, Chu J (2018) Mechanical behaviour of biocemented sands at various treatment levels and relative densities. Acta Geotech. https://doi.org/10.1007/s11440-018-0729-3

13. Zhu T, Dittrich M (2016) Carbonate precipitation through microbial activities in natural environment, and their potential in biotechnology: a review. Front Bioeng Biotechnol 4:4. https://doi.org/10.3389/fbioe.2016. 00004

14. Wang Z, Zhang N, Cai G, Jin Y, Ding N, Shen D (2017) Review of ground improvement using microbial induced carbonate precipitation (MICP). Mar Georesour Geotechnol 35(8):1135-1146

15. Mujah D, Shahin MA, Cheng L (2017) State-of-the-art review of biocementation by microbially induced calcite precipitation (MICP) for soil stabilization. Geomicrobiol J 34(6):524-537

16. Naveed M, Duan J, Uddin S, Suleman M, Hui Y, Li H (2020) Application of microbially induced calcium carbonate precipitation with urea hydrolysis to improve the mechanical properties of soil. Ecol Eng 153: 105885. https://doi.org/10.1016/j.ecoleng.2020.105885

17. Omoregie AI, Palombo EA, Nissom PM (2021) Bioprecipitation of calcium carbonate mediated by ureolysis: a review. Environ Eng Res 26(6):200379

18. Lebron I, Suarez DL (1996) Calcite nucleation and precipitation kinetics as affected by dissolved organic matter at $25^{\circ} \mathrm{C}$ and $\mathrm{pH} 4-7.5$. Geochim Cosmochim Acta 60(15):2765-2776

19. Lebron I, Suarez DL (1998) Kinetics and mechanisms of precipitation of calcite as affected by $\mathrm{PCO}_{2}$ and organic ligands at $25^{\circ} \mathrm{C}$. Geochim Cosmochim Acta 62(3):405-416

20. Lin YP, Singer PC (2005) Inhibition of calcite crystal growth by polyphosphates. Water Res 39:4835-4843

21. Venda Oliveira PJ, Freitas LD, Carmona JPSF (2016) Effect of soil type on the enzymatic calcium carbonate precipitation process used for soil improvement. J Mater Civ Eng 29(4):04016263

22. Canakci H,-Sidik W, Kilic IH (2015) Bacterail calcium carbonate precipitation in peat. Arab J Sci Eng 40: 2251-2260

23. Canakci H, Sidik W, Halil Kilic I (2015) Effect of bacterial calcium carbonate precipitation on compressibility and shear strength of organic soil. Soils Found 55(5):1211-1221

24. Sidik WS, Canakci H, Kilic IH, Celik F (2014) Applicability of biocementation for organic soil and its effect on permeability. Geomech Eng 7(6):649-663

25. Sato A, Kawasaki S, Hata T, Hayashi T (2016) Possibility for solidification of peaty soil by using microbes. Int J GEOMATE 10(22):2071-2076

26. Inagaki Y, Tsukamoto M, Mori H, Sasaki T, Soga K, Al Qabany A, Hata T (2011) The influence of injection conditions and soil types on soil improvement by microbial functions. In: Geo-Frontiers 2011. ASCE Geo-Frontiers 2011 Congress, Dallas, Texas, USA, pp 4021-4030

27. Venda Oliveira PJ, Neves JPG (2019) Effect of organic matter content on enzymatic biocementation process applied to coarse-grained soils. J Mater Civ Eng 31(7):04019121

28. Venda Oliveira PJ, Freitas LD (2020) Effect of the soil type on the biocementation process by enzymatic way. In: Proceedings of the $4^{\text {th }}$ European Conference on Unsaturated Soils E-UNSAT2020, E3S Web of Conferences, vol 195, p 05008. https://doi.org/10.1051/e3sconf/202019505008

29. Safdar M, Mavroulidou M, Gunn MJ, Garelick J, Payne I, Purchase D (2020a) Biocementation of an organic soil using indigenous ureolytic bacteria. 6th International Symposium on Green Chemistry, Sustainable Development and Circular Economy (Greenchem6), Thessaloniki, 20-23 September 2020

30. Safdar MU, Mavroulidou M, Gunn MJ, Garelick J, Payne I, Purchase D (2020b) Innovative methods of ground improvement for railway embankment Peat Fens foundation soil. Géotechnique:1-14. https://doi. org/10.1680/jgeot.19.SiP.030

31. Elworthy J (2012) GALLERY: Council makes urgent plea for $£ 10$ million to tackle county's drought affected roads, The Ely Standard, 12:33 03 April 2012 (online) Available from: https://www.elystandard.co. uk/news/gallery-council-makes-urgent-plea-for-10-million-to-tackle-county-sdrought-affected-roads-11338732. Accessed 18/09/2020

32. BSI (2018) BS EN ISO 14688-1:2018 Geotechnical investigation and testing - identification and classification of soil. Part 1: Identification and description. BSI, London

33. ASTM (1997) D4427-92 (Reapproved 1997) Standard classification of peat samples by laboratory testing. ASTM International, West Conshohocken

34. BSI (1990) BS 1377:1990: Methods of test for soils for civil engineering purposes. Classification tests. BSI, London

35. BSI (2017) BS EN ISO 11508:2017 Soil quality. Determination of particle Density. BSI, London

36. BSI (2014) BS EN ISO 17892-1:2014 Geotechnical investigation and testing. Laboratory testing of soil. Determination of water content BSI, London

37. BSI (2005) BS ISO 10390:2005 Soil quality. Determination of pH. BSI, London 
38. American Society for Testing and Materials (ASTM) (2014) ASTM D2974 - 14: Standard test methods for38. moisture, ash, and organic matter of peat and other organic soils. ASTM International, West Conshohocken

39. BSI (2012) BS ISO 13099-2:2012, Colloidal systems. Methods for zeta potential determination-Part 2: Optical methods. BSI, London

40. Chapman HD (1965) Cation-exchange capacity. In: Black CA (ed) Methods of soil analysis -chemical and microbiological properties. Agronomy, vol 9, pp 891-901

41. Boquet E, Boronat A, Ramos-Cormenzana A (1973) Production of calcite (calcium carbonate) crystals by soil bacteria is a general phenomenon. Nature 246:527-529

42. Marvasi M, Gallagher KL, Casillas Martinez L et al (2012) Importance of B4 medium in determining organomineralization potential of bacterial environmentalisolates. Geomicrobiol J 29(10):916-924

43. Singhal N, Kumar M, Kanaujia PK, Virdi JS (2015) MALDI-TOF mass spectrometry: an emerging technology for microbial identification and diagnosis. Front Microbiol 6:791. https://doi.org/10.3389/ fmicb.2015.00791

44. Ge MC, Kuo AJ, Liu KL, Wen YH, Chia JH, Chang PY, Lee MH, Wu TL, Chang SC, Lu JJ (2016) Routine identification of microorganisms by matrix-assisted laser desorption ionization time-of-flight mass spectrometry: success rate, economic analysis, and clinical outcome. J Microbiol Immunol Infect 50(5): 662-668. Epub 2016/07/19. https://doi.org/10.1016/j.jmii.2016.06.002

45. Lai YH, Wang YS (2017) Matrix-assisted laser desorption/ionization mass spectrometry: mechanistic studies and methods for improving the structural identification of carbohydrates. Mass Spectrom (Tokyo) 6(Spec Iss 2):S0072 Epub 2017/09/30

46. Florio W, Tavanti A, Barnini S, Ghelardi E, Lupetti A (2018) Recent advances and ongoing challenges in the diagnosis of microbial infections by MALDI-TOF mass spectrometry. Front Microbiol 9:1097. https:// doi.org/10.3389/fmicb.2018.01097

47. Fang L, Xu H, Ren X, Li X, Ma X, Zhou H, Hong G, Liang X (2020) Epidemiology and risk factors for carbapenem-resistant Klebsiella pneumoniae and subsequent MALDI-TOF MS as a tool to cluster KPC-2producing Klebsiella pneumoniae, a retrospective study. Front Cell Infect Microbiol 10:462. https://doi.org/ $10.3389 /$ fcimb. 2020.00462

48. Seng P, Drancourt M, Gouriet F, la Scola B, Fournier PE, Rolain JM, Raoult D (2009) Ongoing revolution in bacteriology: routine identification of bacteria by matrix-assisted laser desorption ionization time-of-flight mass spectrometry. Clin Infect Dis 49:543-551

49. Xu S, Zhou C, Zhang P, Feng C, Zhang T, Sun Z, Zhuang H, Chen H, Chang Q, Jiang R, Li H, Ni Y (2020) Diagnostic performance of MALDI-TOF MS compared to conventional microbiological cultures in patients with suspected endophthalmitis. Ocul Immunol Inflamm 28(3):483-490. https://doi.org/10.1080/09273948. 2019.1583346

50. Zhou M, Yang Q, Kudinha T, Zhang L, Xiao M, Kong F, Zhao Y, Xu Y-C (2016) Using matrix-assisted laser desorption ionization-time of flight (MALDI-TOF) complemented with selected 16S rRNA and gyrB genes sequencing to practically identify clinical important viridans group Streptococci (VGS). Front Microbiol 7:1328. https://doi.org/10.3389/fmicb.2016.01328

51. Sauget M, van der Mee-Marquet N, Bertran X, Hocquet D (2016) Matrix-assisted laser desorption ionization-time of flight mass spectrometry can detect Staphylococcus aureus clonal complex 398. J Microbiol Methods 127:20-23

52. Deng J, Fu L, Wang R, Yu N, Ding X, Jiang L, Fang Y, Jiang C, Lin L, Wang Y, Che X (2014) Comparison of MALDI-TOF MS, gene sequencing and the Vitek 2 for identification of seventy-three clinical isolates of enteropathogens. J Thorac Dis 6(5):539-544

53. Croxatto A, Prod'hom G, Greub G (2012) Applications of MALDI-TOF mass spectrometry in clinical diagnostic microbiology. FEMS Microbiol Rev 36(2):380-407 Epub 2011/11/19

54. Tan KE, Ellis BC, Lee R, Stamper PD, Zhang SX, Carroll KC (2012) Prospective evaluation of a matrix-assisted laser desorption ionization-time of flight mass spectrometry system in a hospital clinical microbiology laboratory for identification of bacteria and yeasts: a bench-by-bench study for assessing the impact on time to identification and cost-effectiveness. J Clin Microbiol 50(10): 3301-3308 Epub 2012/08/03

55. Wilson DA, Young S, Timm K, Novak-Weekley S, Marlowe EM, Madisen N, Lillie JL, Ledeboer NA, Smith R, Hyke J, Griego-Fullbright C, Jim P, Granato PA, Faron ML, Cumpio J, Buchan BW, Procop GW (2017) Multicenter evaluation of the Bruker MALDI Biotyper CA system for the identification of clinically important bacteria and yeasts. Am J Clin Pathol 147(6):623-631. https://doi.org/10.1093/ajcp/aqw225

56. Fergusson CH, Coloma JMF, Valentine MC, Haeckl FPJ, Linington RG (2020) Custom matrix-assisted laser desorption ionization- time of flight mass spectrometric database for identification of environmental isolates of the genus Burkholderia and related genera. Appl Environ Microbiol 86:e0354-e0320. https:// doi.org/10.1128/AEM.00354-20 
57. Ruelle V, Moualij EI, Zorzi WB, Ledent P, Pauw ED (2004) Rapid identification of environmental bacterial strains by matrix-assisted laser desorption/ionization time-of-flight mass spectrometry. Rapid Commun Mass Spectrom 18:2013-2019. https://doi.org/10.1002/rcm.1584

58. Dieckmann R, Graeber I, Kaesler I, Szewzyk U, von Döhren H (2005) Rapid screening and dereplication of bacterial isolates from marine sponges of the sula ridge by intact-cell-MALDI-TOF mass spectrometry (ICM-MS). Appl Microbiol Biotechnol 67:539-548

59. Uhlik O, Strejcek M, Junkova P, Sanda M, Hroudova M, Vlcek C, Mackova M, Macek T (2011) Matrixassisted laser desorption ionization (MALDI)-time of flight mass spectrometry- and MALDI biotyper-based identification of cultured biphenyl-metabolizing bacteria from contaminated horseradish rhizosphere soil. Appl Environ Microbiol 77:6858-6866

60. Kumar R, Sharma RC (2020) Microbial diversity in relation to physico-chemical properties of hot water ponds located in the Yamunotri landscape of Garhwal Himalaya. Heliyon 6(9):e04850. https://doi.org/10. 1016/j.heliyon.2020.e04850

61. Karolski B, Cardoso LOB, Gracioso LH, Nascimento CAO, Perpetuo EA (2018) MALDI-Biotyper as a tool to identify polymer producer bacteria. J Microbiol Methods 153:127-132

62. Mulet M, Montaner M, Román D, Gomila M, Kittinger C, Zarfel G, Lalucat J, García-Valdés E (2020) Pseudomonas Species Diversity Along the Danube River Assessed by rpoD Gene Sequence and MALDITOF MS Analyses of Cultivated Strains. Front Microbiol 11:2114. https://doi.org/10.3389/fmicb.2020. 02114

63. Gómez-Velásquez JC, Loaiza-Díaz N, Norela Hernández G, Mesa-Arango AC (2020) Development and validation of an in-house library for filamentous fungi identification by MALDI-TOF MS in a clinical laboratory in Medellin (Colombia). Microorganisms 8:1362. https://doi.org/10.3390/ microorganisms8091362

64. American Public Health Association/American Water Works Association/ Water Environmental Federation (APHA/AWWA/WEF) (2005) Standard methods for the examination of water and wastewater. Washington, DC

65. Safdar MU, Mavroulidou M, Gunn MJ, Purchase D, Garelick J, Payne I (2021) Electrokinetic biocementation of an organic soil. Sustain Chem Pharm 21:100405. https://doi.org/10.1016/j.scp.2021. 100405

66. CDC/NIH (U.S. Department of Health and Human Services, Centers for Disease Control and Prevention, \& National Institutes of Health) (2007) In: Chosewood LC, Wilson DE (eds) Biosafety in microbiological and biomedical laboratories, 5th edn. U.S. GovernmentPrinting Office, Washington See www.cdc.gov/od/ohs/ biosfty/bmbl5/bmbl5toc.htm (accessed 08/04/2020)

67. Bundesanstalt für Arbeitsschutz und Arbeitsmedizin (BAUA) (2015) Technische Regel für Biologische Arbeitsstoffe: TRBA 466 Einstufung von Prokaryonten (Bacteria und Archaea) in Risikogruppen, GMB1. Nr. 46-50, date 25 August 2015, p. 910 https:/www.baua.de/DE/Angebote/Rechtstexte-und-TechnischeRegeln/Regelwerk/TRBA/ TRBA-466.html

68. DeJong JT, Mortensen BM, Martinez BC, Nelson DC (2010) Bio-mediated soil improvement. Ecol Eng 36(2): 197-210

69. HMG (Her Majesty's Government) (2018) The water supply (water quality) (amendment) regulations 2018 (S.I. 2018/706). The Stationery Office Limited, London See http://www.legislation.gov.uk/uksi/2018/706/ made (accessed 05/07/2019)

70. Keykha HA, Mohamadzadeh H, Asadi A, Kawasaki S (2018) Ammonium-free carbonate-producing bacteria as an ecofriendly soil biostabilizer. Geotech Test J. https://doi.org/10.1520/GTJ20170353. ISSN0149-6115

71. Gomez MG, Anderson CM, Graddy CMR, JT DJ, Nelson DC, Ginn TR (2017) Large-scale comparison of bioaugmentation and biostimulation approaches for biocementation of Sand. J Geotech Geoenviron 143(5): 04016124

72. Almajed A (2017) Enzyme induced carbonate precipitation (EICP) for soil improvement. PhD Thesis, Arizona State Univesity. Available from: https://repository.asu.edu/items/45504 Accessed 1 July 2021

73. Al Qabany A, Soga K (2013) Effect of chemical treatment used in MICP on engineering properties of cemented soils. Géotechnique 63(4):331-339

74. Ng WS, Lee ML, Tan CK, Hii SL (2014) Factors affecting improvement in engineering properties of residual soil through microbial-induced calcite precipitation. J Geotech Geoenviron 140(5):04014006

75. Harkes MP, Van Paassen LA, Booster JL, Whiffin VS, Van Loosdrecht MCM (2010) Fixation and distribution of bacterial activity in sand to induce carbonate precipitation for ground reinforcement. Ecol Eng 36:112-117 


\section{Affiliations}

M. U. Safdar ${ }^{1}$ - M. Mavroulidou ${ }^{1} \cdot$ M. J. Gunn ${ }^{1} \cdot$ D. Purchase ${ }^{2} \cdot$ C. Gray $^{3} \cdot$ I. Payne ${ }^{4} \cdot$ J. Garelick $^{5}$

1 Division of Civil and Building Services Engineering, London South Bank University, London, UK

2 School of Natural Sciences, Faculty of Science and Technology, Middlesex University, London, UK

3 London South Bank University, London, UK

4 Geotechnical Asset Management, East Anglia Route, Network Rail, London, UK

5 Design Delivery, Network Rail, London, UK 